\title{
Patterns of parasitism by Eutrombicula alfreddugesi (Oudemans) (Acari, Trombiculidae) in three species of Tropidurus Wied (Squamata, Tropiduridae) from Cerrado habitat of Central Brazil
}

\author{
André L. G. de Carvalho; Alexandre F. B. de Araújo \& Hélio R. da Silva
}

Laboratório de Herpetologia, Departamento de Biologia Animal, Instituto de Biologia, Universidade Federal Rural do Rio de Janeiro. Caixa Postal 74524, 23851-970 Seropédica, Rio de Janeiro, Brasil.

E-mail: andreluiz.carvalho@ig.com.br; araujo@ufrrj.br; helio@ufrrj.br

\begin{abstract}
This study concerns the patterns of parasitism by the larvae of Eutrombicula alfreddugesi (Oudemans, 1910) on three species of Tropidurus Wied, 1820 from Cerrado habitats of Central Brazil: T. oreadicus Rodrigues, 1987 ( $\mathrm{n}$ $=97)$, $T$. itambere $(\mathrm{n}=85)$ and $T$. torquatus (Wied, 1820) (two samples $\mathrm{n}=75, \mathrm{n}=23)$. The highest prevalence value was observed in $T$. itambere ( $88.2 \%$ ), followed by $T$. oreadicus $(87.6 \%)$, and $T$. torquatus $(17.3 \%$ and $65.2 \%)$. The most important sites of infestation were the mite pockets and skin folds, especially on the neck and inguinal region. Tropidurus itambere Rodrigues, 1987 was the most heavily parasitized species (mean intensity of infestation: $36.67 \pm$ 41.09), followed by $T$. oreadicus $(15.38 \pm 21.08)$, and $T$. torquatus from Unaí, Minas Gerais (12.13 \pm 21.09$)$. The lowest intensity of infestation was found in $T$. torquatus from urban and periurban areas of Brasilia, Distrito Federal $(1.97 \pm$ 5.43). The analysis did not indicate differences in intensity of infestation between sexes for any of the species. Differences in the patterns of parasitism among the three lizard species may be related to the morphological and numerical variation of the skin folds (especially mite pockets), to the degree of conservation of the host's habitats, and to selective processes related to reduction of damage to the host's bodies, to the evolution of mechanisms of decreasing illness transmission by parasites, or even to some behavioral traits of the lizards.
\end{abstract}

KEY WORDS. Lizards; mites; ectoparasitism.

RESUMO. Padrões de parasitismo por Eutrombicula alfreddugesi (Oudemans) (Acari, Trombiculidae) em três espécies de Tropidurus Wied (Squamata, Tropiduridae) do Cerrado brasileiro. Estudaram-se os padrões de parasitismo por larvas de Eutrombicula alfreddugesi (Oudemans, 1910) em três espécies de Tropidurus Wied, 1820 do Cerrado brasileiro: T. oreadicus Rodrigues, $1987(\mathrm{n}=97)$, T. itambere $(\mathrm{n}=85)$ e $T$. torquatus (Wied, 1820) (duas amostras $\mathrm{n}=75, \mathrm{n}=23)$. A maior prevalência foi observada em $T$. itambere Rodrigues, $1987(88,2 \%)$, seguido por $T$. oreadicus $(87,6 \%)$ e $T$. torquatus $(17,3 \%$ e $65,2 \%)$. Os sítios de infestação mais importantes foram as bolsas de ácaro e dobras de pele, em especial do pescoço e região inguinal. Tropidurus itambere foi a espécie mais intensamente parasitada (intensidade média de infestação: $36,67 \pm 41,09)$, seguido por $T$. oreadicus $(15,38 \pm 21,08)$ e $T$. torquatus de Unaí, Minas Gerais $(12,13 \pm 21,09)$. A intensidade parasitária mais baixa foi registrada para os indivíduos de $T$. torquatus oriundos de áreas urbanas e periurbanas de Brasília, Distrito Federal $(1,97 \pm 5,43)$. As analises não indicaram diferenças nas intensidades parasitárias entre os sexos para nenhuma das espécies. As diferenças no padrão de parasitismo entre as três espécies de lagartos podem estar relacionadas a variações morfológicas e numéricas das dobras de pele (em especial das bolsas de ácaro), ao grau de conservação do hábitat dos hospedeiros, a processos seletivos relacionados à redução de danos ao corpo dos hospedeiros, à evolução de mecanismos de diminuição da transmissão de doenças por parasitas, ou até mesmo a aspectos comportamentais dos lagartos.

PALAVRAS-CHAVE. Lagartos; ácaros; ectoparasitismo.

The genus Eutrombicula Ewing, 1938 (Trombiculidae) includes mites commonly found as ectoparasites on vertebrates (Vercammen-Grandjean \& Audy 1965, Brennan \& Reed 1974). In the Americas, Eutrombicula alfreddugesi (Oudemans, 1910) is one of the most widespread species. It commonly parasitizes rep- tiles, mainly lizards and snakes (HYLAND 1950, VERCAMMENGrandjeAn \& Audy 1965, Zippel et al. 1996, Daniel \& Stekol'Nikov 2004, KLUKOWSKI 2004).

The relationship between lizards and mites seems to be so old that somelizard families independently developed skin folds 
(BAuer et al. 1990, Frost 1992, McGuire 1996, Frost et al. 2001), forming structures known as "mite pockets" (RodRIGUEs 1987) in different parts of the body where the parasites aggregate.

The presence of mite pockets and the existence of patterns of parasitism in lizards were discussed in several earlier studies (Arnold 1986, Benton 1987, Bauer et al. 1990, 1993). However, the main hypothesis proposed by ARNold (1986) to explain this subject remains insufficiently tested. That author suggested that mite pockets are adaptive and their presence would guarantee damage reduction caused by the parasites, by limiting the distribution area over the hosts' bodies. These structures seem to form microhabitats perfectly suited for occupation by mites. However, BAUER \& al. $(1990,1993)$ disagree with this idea, considering the appearance of mite pockets as independent phylogenetic events without adaptive value.

Although morphological transformations and speciation events may directly influence the relationships between host and parasites, few workers have attempted to elucidate these co-evolutionary processes (ARnold 1986, BAUER et al. 1990, 1993, Benton 1987). Most papers on the subject have dealt with the description of new parasite taxa or the intensity and prevalence of parasitism (Vercammen-Grandjean \& Audy 1965, CunhaBarros \& Rocha 2000, Durden et al. 2002, Cunha-Barros et al. 2003, GarCíA-DE-LA-PeÑa et al. 2004, KLUKOWSKI 2004). Mite pockets are also useful in the studies of lizard taxonomy (RodRIGUES 1987, Frost 1992, McGuire 1996, Frost et al. 2001) and the presence and morphology of these structures are used as characters in analyses that intend to understand the evolutionary history and the relationship of studied taxa

The relationship between social life (aggregation) of lizards and damage caused by parasites has also been explored. SoRCl et al. (1997) conducted experiments with Lacerta vivipara Jaquin, 1787 (Lacertidae) parasitized by mites of the genus Ophionyssus Mégnin, 1883 (Mesostigmata). Their results suggest that ectoparasites do not represent a negative factor to denser populations, which would dilute the intensity of infestation across the aggregation.

In southeastern Brazil, patterns of infestations by mites have been investigated in lizard species inhabiting restinga (coastal sand dune) habitats. CunHA-BarRos \& Rocha (2000) studied five lizard species, of three families, at the Restinga da Barra de Maricá, Rio de Janeiro. Their main goal was to test the existence of possible differences in the pattern of parasitism related to seasonal environmental variations, although their hypothesis has not been confirmed. Cunha-Barros et al. (2003) compared the pattern of parasitism in four lizard species, of three families, at the Restinga de Jurubatiba, also in the State of Rio de Janeiro, and found some differences when compared their results to those of the previous study (CUNHA-BARROS \& RoCHA 2000).

Here we discuss the patterns of parasitism by larvae of Eutrombicula alfreddugesi on three species of Tropidurus (Wied, 1820) from Cerrado habitat of Central Brazil, evaluating parameters such as the intensity and prevalence of parasitism, and parasite distribution over the hosts' bodies. We further analyze the variations in the patterns of parasitism and relate them to ecological aspects of lizard species.

\section{MATERIAL AND METHODS}

\section{Recording of Data}

To study the distribution of the larvae of Eutrombicula alfreddugesi in three species of Tropidurus from Cerrado habitat of Central Brazil, we examined 280 preserved adult specimens in the Herpetological Collection of Universidade de Brasília (CHUNB). Samples of Tropidurus oreadicus Rodrigues, 1987 ( $n=$ 97) and T. itambere Rodrigues, $1987(n=85)$ are from Parque Estadual da Serra dos Pirineus, Pirinópolis, State of Goiás; T. torquatus (Wied, 1820) ( $n=75$ ) are from urban and periurban areas (fragments of Cerrado located at thetown's edge) of Brasília, Distrito Federal, and from Cerrado areas $(n=23)$ located next to the city of Unaí, State of Minas Gerais. We searched for ectoparasites in the skin folds and on the body of each lizard. The number and position of mites in thelizards' bodies were recorded. In order to evaluate possible site fidelity, the body of the lizard was divided in 15 sites of parasite infestation (Fig. 1).

The snout-vent length (SLV) of each specimen was measured using a digital caliper (to the nearest $0.1 \mathrm{~mm}$ ) and were used to test the relationship between host body size and intensity of infestation. Sexual variation in intensity of infestation and distribution on the body was also investigated. Sex was determined by observation of color pattern - males have dark marks under the thighs, abdomen, and precloacal area, and females have reddish-orange venters (RodRIGUES 1987) - and by direct observation of the gonads for the animals with no evident secondary sexual characters.

Samples of T. torquatus are from two different areas of Cerrado. One from relatively undisturbed habitats (Unaí) and the other from impacted and heavily al tered (e.g., burned) habitats with patchy vegetation (Brasilia). These samples allowed us to assess the effect of Cerrado degradation on the patterns of ectoparasitism in Tropidurus species.

\section{Statistical Analyses}

The hypothesis of random distribution of mites on the lizards was analyzed using the index of dispersion expressed as variance/mean of the number of mites per body region (adapted from KREBS 1998). After the index was determined for each individual, the average of the index of dispersion for each species was calculated and used to determine the pattern of distribution of mites, by goodness-of-fit test to the Poisson distribution (KREBS 1998).

We used the non parametric Mann-Whitney test to verify the hypothesis of independence of infestation sites on the lizard (between left and right sides). Differences in the prevalence of parasitism among host species were tested using chi-square test, followed by a Z-test, performed for pairs of species.

To investigate variations in the intensity of infestation 


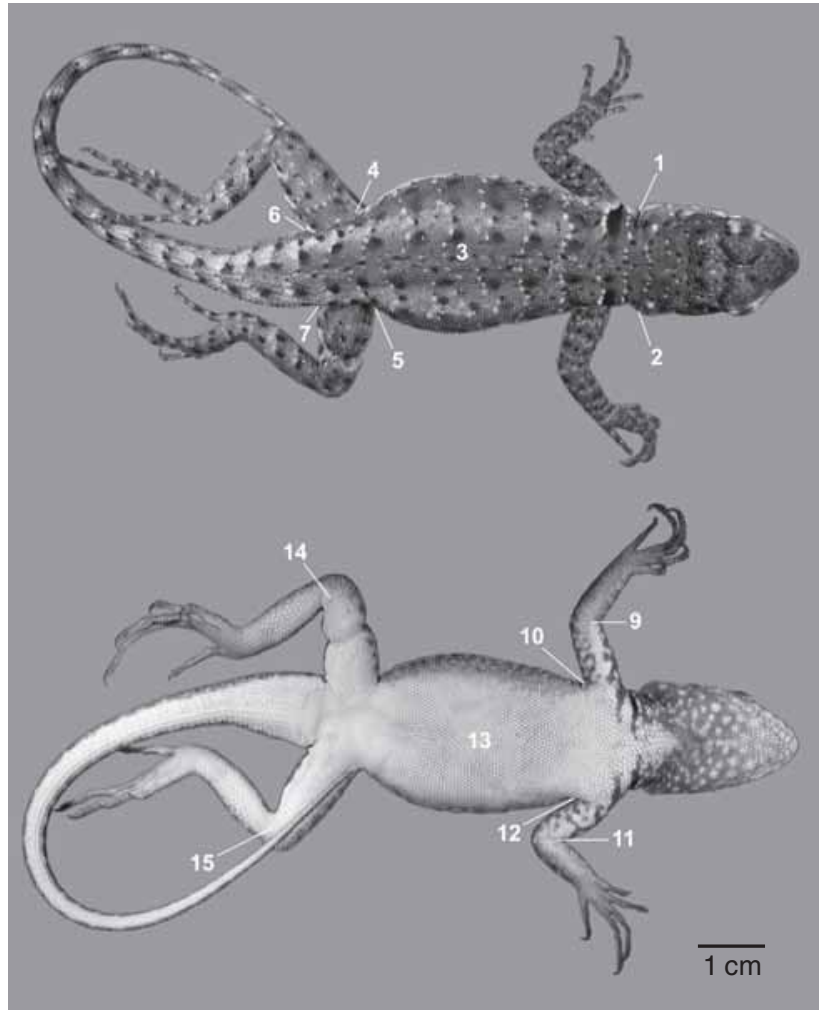

Figure 1. Tropidurus torquatus dorsal and ventral views indicating sites of mite infestation, where: (1-2) left and right neck mite pockets, (3) dorsum, (4-5) left and right inguinal mite pockets, (67) left and right post femoral region, (8) tail, (9-10) forelimbs, (11-12) right and left armpits, (13) venter, (14-15) hindlimbs.

and in the pattern of distribution of mite larva in different regions of lizard's body, the data were log-transformed, submitted to ordination using a principal component analysis (PCA, correlation matrix). The hypothesis of differences be tween species, populations and between sexes were tested with a discriminant analysis. The two samples of $\mathrm{T}$. torquatus were analyzed independently.

We performed a linear regression analysis to investigate the relationship between host size (SVL) and intensity of infestation. Each analysis was done with all specimens of each species and repeated separately by sex. All statistical tests were executed in the software SYSTAT 7.0, except the Z-test that was executed in the software MICROSTAT.

\section{RESULTS}

Table I presents the prevalence and parasitic intensity for thelizards. Thehighest prevalencevaluewas observed in Tropidurus itambere, followed by T. oreadicus, and T. torquatus. In the last species, the highest prevalence was obtained for Unaí population.
The chi-square test indicated that the prevalence of parasitism differed among the four populations of Tropidurus $\left(\chi^{2}=\right.$ 119.977, $\mathrm{gl}=3, \mathrm{p}<0.001)$. The Z-test showed that only $\mathrm{T}$. itambere and $T$. oreadicus did not differ in prevalence of parasites $(Z=0.124, p=0.451)$. Only $T$. torquatus from Brasília was different from the others with respect to sexual differences in prevalence of mite larvae, but marginally $(Z=1.677, p=0.047)$.

The eigenvalues generated by the PCA and the explained variance are presented in table II (see also Fig. 2). The most important site of infestation was the neck, followed by the inguinal region, which presented the highest values in the first principal component. We observed a tendency of an inverse correlation between principal component values representing the number of mites in the neck and inguinal region, when these were contrasted with those for the axillary region. However, the linear regression test did not confirm the significance of this tendency.

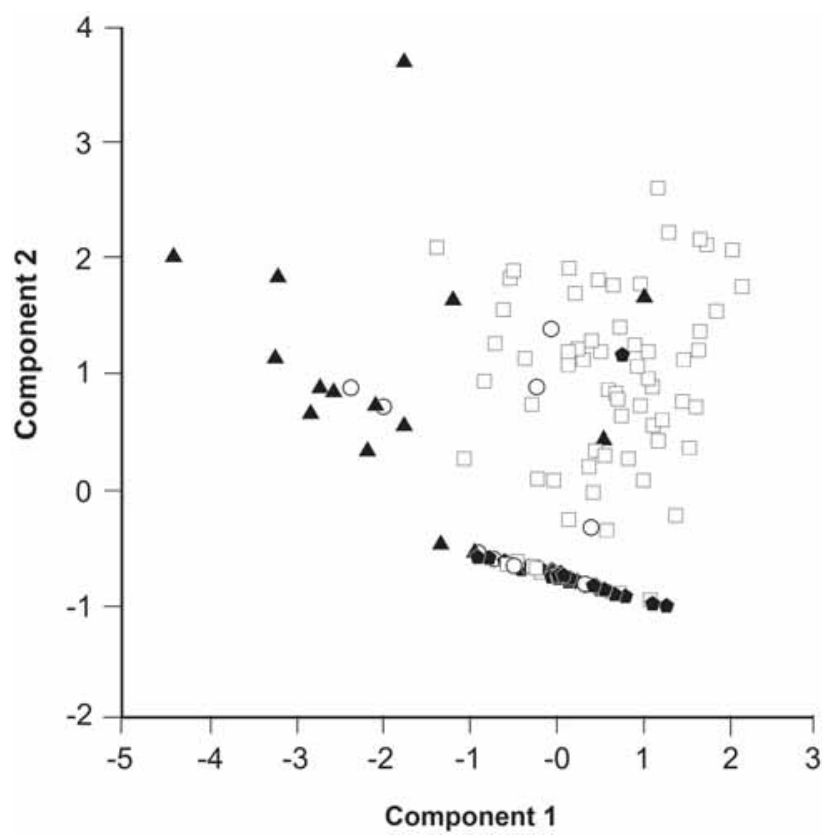

Figure 2. Scatterplot of the first and second principal components from principal component analysis for distribution of mites on the most important sites of infestation for the three species of Tropidurus analysed. Square: Tropidurus itambere, Pentagon: T. oreadicus, Circle: T. torquatus from Brasilia, Distrito Federal, Triangle: T. torquatus from Unaí, Minas Gerais.

The discriminant analysis for PCA scores (using neck, axillary and inguinal sites) indicated differences in the intensity of infection for the three lizard species (Wilks' $\lambda=0.259$; $F=54.933 ; d f=9.666 ; p<0.001$ ). Tropidurus itambere was the most heavily parasitized species, followed by T. oreadicus, and 
Table I. Mean size (snout-vent length in $\mathrm{mm}$ ) + standard diviation, number of specimens, prevalence, and mean intensity of parasitism by sex and total for Tropidurus populations. (DF) Distrito Federal, (MG) Minas Gerais.

\begin{tabular}{|c|c|c|c|c|c|c|c|c|c|c|}
\hline \multirow{2}{*}{ Species } & \multirow[t]{2}{*}{ Size } & \multirow{2}{*}{\multicolumn{3}{|c|}{$\frac{\text { Specimens }}{\text { Male Female Total }}$}} & \multicolumn{3}{|c|}{ Prevalence (\%) } & \multicolumn{3}{|c|}{ Mean Intensity of Infestation } \\
\hline & & & & & Male & Female & Total & Male & Female & Total \\
\hline Tropidurus itambere & $57.63 \pm 9.73$ & 50 & 35 & 85 & 92.00 & 82.86 & 88.23 & $46.36 \pm 47.40$ & $22.83 \pm 24.43$ & $36.67 \pm 41.09$ \\
\hline Tropidurus oreadicus & $67.82 \pm 14.47$ & 60 & 37 & 97 & 86.67 & 89.19 & 87.63 & $17.82 \pm 24.96$ & $51143+1175$ & $15.38 \pm 21.08$ \\
\hline Tropidurus torquatus, DF & $88.62 \pm 15.74$ & 27 & 48 & 75 & 11.11 & 20.83 & 17.33 & $2.15 \pm 6.64$ & $1.87 \pm 4.49$ & $1.97 \pm 5.43$ \\
\hline Tropidurus torquatus, MG & $90.97 \pm 13.04$ & 14 & 9 & 23 & 78.57 & 44.44 & 65.22 & $11.64 \pm 18.19$ & $12.89 \pm 26.24$ & $12.13 \pm 21.09$ \\
\hline
\end{tabular}

Table II. Eigenvalues and explained variance by the components (\%) obtained using principal components analysis (PCA), based on infestation values.

\begin{tabular}{lrrr}
\hline \multirow{2}{*}{ Site of Infestation } & \multicolumn{3}{c}{ Components } \\
\cline { 2 - 4 } & \multicolumn{1}{c}{ } & \multicolumn{1}{c}{3} \\
\hline Armpit & -0.063 & 0.994 & 0.083 \\
Lateral neck & 0.822 & -0.034 & 0.568 \\
Inguinal region & 0.818 & 0.112 & -0.565 \\
Explained variance & 44.966 & 33.425 & 21.608 \\
\hline
\end{tabular}

T. torquatus from Unaí. The lowest intensity of infestation was found in T. torquatus from Brasilia (Tab. I). The results of the discriminant analysis did not indicate differences in intensity of infestation between sexes, for any species.

The intensity of infestation for each body region of the lizards is presented in table III. In Tropidurus itambere and T. oreadicus the highest intensity of infestation occurred in mite pockets on the neck and inguinal region and the lowest occurred in the axillary region (note that $\mathrm{T}$. oreadicus had no parasites in the axillary region, and both species lack mite pockets in this region). Tropidurus torquatus presented the most similar distribution of ectoparasites in the three major areas of the body (neck, axillary, and inguinal region). Of the three species, T. torquatus was the only where parasites were present in other regions of body besides neck, axillary, and inguinal re gions, although at low densities. According to the average index of dispersion (AID >1) and adjust to the Poisson (random) distribution (Tab. IV), the distribution of parasites over the body was aggregated for all species of Tropidurus.

The results of the Mann-Whitney test for differences in intensity of parasitism between body sides indicated that the intensity of parasitism of the inguinal region of $\mathrm{T}$. itambere $\left(U=4349.0, \chi^{2}=5.91, d f=169, p=0.015\right)$ and neck region of T. oreadicus $\left(U=5959.0, \chi^{2}=10.54, d f=193, p=0.001\right.$ ) are significantly different. Intensity of parasitism was significantly related to body size in Tropidurus itambere (male: $r^{2}=0.309$, $p=0.000$; female: $r^{2}=0.176, p=0.026$; total: $r^{2}=0.261$, $p=0.000$ ) and marginally in T. oreadicus, only for the pooled sample $\left(r^{2}=0.046, p=0.058\right)$. However, the $r^{2}$ values for these species were low.

\section{DISCUSSION}

At first glance, one could assume that the similarity in prevalence of mites between $\mathrm{T}$. oreadicus and T. itambere could bethe result of the great similarity in morphology (mostly body shape) and ecology (especially in the use of microhabitats in rocky outcrops and prey items) between these sintopic species (FARIA \& ARAUjo 2004). In addition, parasites may not select hosts. When compared to the other two lizard species, Tropidurus torquatus had a lower prevalence of mites. Differences in prevalence and intensity of infestation may be related to oscillations in mite populations from different habitats of the lizards. Another possibility is that differences are associated to mite pockets and skin fold morphology. For instance, in T. torquatus deep mite pockets are absent. Therefore, this lizard may be more prone to lose their ectoparasites during the collecting and fixation handling processes, resulting in a falselower intensity, and perhaps prevalence. This may be evidenced by studies conducted using freshly collected and killed specimens of T. torquatus, in which higher mite intensities and prevalence than in the present study were found (CUNHA-BARROS \& RochA 2000, Cunha-Barros et al. 2003).

When the samples of $\mathrm{T}$. torquatus from different Cerrado localities are compared, their prevalence of mites differed significantly. The lowest prevalence was recorded in lizards from urban and periurban areas of Brasília; this may be related to decrease in parasite densities in degraded areas. Indeed, as described by CLOPTON \& GoLD (1993), populations of Eutrombicula alfreddugesi are susceptible to environmental variations, presenting density changes through a gradient of varying degrees of degradation.

Assuming our samples are representative of the populations from which they were collected, the equal prevalence between sexes for all the species (except for T. torquatus from Brasília) may be the result of low selectivity by the parasites. Only in T. torquatus from Brasilia did the sexes differ marginally in parasite prevalence, which may possibly be due to the rarity of parasitism (low prevalence) in the urban and periurban populations. In this case, even small variation in the sample could have caused the perceived differences between sexes, generating a false result.

The use of the mite pockets and skin folds by the larvae

Revista Brasileira de Zoologia 23 (4): 1010-1015, dezembro 2006 
Table III. Average intensity of infestation for Tropidurus populations per site of infestation. (DF) Distrito Federal, (MG) Minas Gerais.

\begin{tabular}{lcccc}
\hline \multicolumn{1}{c}{ Site of Infestation } & T. itambere & T. oreacidus & T. torquatus, DF & T. torquatus, MG \\
\hline Armpit & $0.01 \pm 0.11$ & - & $0.17 \pm 0.84$ & $3.22 \pm 5.26$ \\
Right armpit & $0.01 \pm 0.11$ & - & $0.04 \pm 0.25$ & $1.30 \pm 2.53$ \\
Left armpit & - & - & $0.13 \pm 0.81$ & $1.91 \pm 4.64$ \\
Lateral neck & $21.46 \pm 27.86$ & $15.04 \pm 20.98$ & $1.53 \pm 4.50$ & $3.83 \pm 6.46$ \\
Right lateral neck & $13.45 \pm 20.77$ & $9.76 \pm 17.41$ & $0.64 \pm 2.35$ & $2.09 \pm 3.92$ \\
Left lateral neck & $8.01 \pm 13.24$ & $5.28 \pm 8.83$ & $0.87 \pm 2.81$ & $1.74 \pm 2.88$ \\
Inguinal region & $15.20 \pm 24.75$ & $0.17 \pm 1.72$ & $0.27 \pm 1.47$ & $3.70 \pm 10.22$ \\
Right inguinal region & $9.85 \pm 17.29$ & $0.09 \pm 0.91$ & $0.13 \pm 0.93$ & $2.26 \pm 6.22$ \\
Left inguinal region & $5.35 \pm 12.84$ & $0.08 \pm 0.81$ & $0.14 \pm 1.04$ & $1.43 \pm 4.23$ \\
Dorsum & - & - & - & $0.09 \pm 0.42$ \\
Post-femoral region & - & - & - & - \\
Right post-femoral region & - & - & - & $0.83 \pm 3.75$ \\
Left post-femoral region & - & - & & $0.22 \pm 0.85$ \\
\hline
\end{tabular}

* Tropidurus torquatus presented parasites out of the granular neck region $(0.478 \pm 1.880)$.

Table IV. Average index of dispersion (AID), chi-squared value $\left(\chi^{2}\right)$, adjust to the Poisson distribution and pattern of distribution of mites for Tropidurus populations. (DF) Distrito Federal, (MG) Minas Gerais. For all the species: $p=0.000$ and distribution =aggregated.

\begin{tabular}{lccrc}
\hline \multicolumn{1}{c}{ Species } & N & DF & AID & $\chi^{2}$ \\
\hline Tropidurus itambere & 74 & 14 & 19.698 & 275.776 \\
Tropidurus oreadicus & 85 & 14 & 12.135 & 169.895 \\
Tropidurus torquatus, DF & 13 & 14 & 6.174 & 86.444 \\
Tropidurus torquatus, MG & 16 & 14 & 4.889 & 68.449 \\
\hline
\end{tabular}

of E. alfreddugesi may be related to two main factors that appear to influence the pattern of distribution of parasites over the lizard's body. First, the larvae may actively search for the pockets and folds. Second, skin folds and mite pockets (with small and granular scales) may offer protection against mechanical impacts, insulation, and dehydration (CUNHA-BARROS $\&$ Rocha 2000, Cunha-Barros et al. 2003, Garcia-De-La-Peña et al 2004) assuring that, once the larvae is fixed there, it may not be easily removed. Therefore, the probability of finding larvae at that site is increased. Tropidurus itambere has two pockets in the neck and another in the inguinal region, and had the highest intensity of infestation. Tropidurus oreadicus has only two deep and oblique pockets in the neck region, and had the second highest intensity of infestation. In T. torquatus, which has only shallow skin folds (not forming "true" pockets), the intensity of infestation was the lowest among the three species compared here.

The relationship between skin folds and pockets, and the gradient of intensity of infestation could indicate a drawback in possessing these structures. However, as proposed by ARNOLD (1986), investment in specialized areas for mite installation could save more important areas of the lizard's body against infestation, actually diminishing the overall damage caused by the parasites.

Alternatively, other factors may explain the increase in intensity of infestation in specific regions of the body (folds and pockets). One possibility is that guarding and protecting a set of mites may play an important role in decreasing the chances of parasite exchanges and transmission of diseases. Our suggestion adds another advantage in offering protection to the mites to ARnold's (1986) hypothesis. Tests of such a hypothesis may be possible as we learn more about the relationships between mites and the transmissions of hemoparasites to lizards.

Intensity of infestation was similar between the sides of the lizard's bodies, except in the inguinal region of T. itambere and the neck of $T$. oreadicus. This may suggest that the sites of infestation are not isolated and that mites may migrate from site to site. Another possibility is that incoming mites may only fix themselves in sites not yet overcrowded. With a continuous influx of newly arriving mites, all sites tend to become equally infested.

Although the relationship between body size and intensity of infestation should be expected (older and larger lizards presenting a higher load than younger and smaller ones), assuming all size classes use the same microhabitats, this assumption was not strongly supported by our data. Despite the observed tendency of increasing intensity of infestation with increasing host size (only for $T$. itambere and $T$. oreadicus), the fit $\left(r^{2}\right)$ was relatively weak. No correlation between lizard body size and parasitic infestation was described by some workers (Cunha-Barros et al. 2003, Garcia-de-la-Peña et al. 2004). However, this lack of relationship does not hold true for all lizards (Cunha-Barros \& Rocha 2000). Even when data from the same 
species from different areas are compared, as in the case of $\mathrm{T}$. torquatus (Cunha-Barros \& Rocha 2000, Cunha-Barros et al. 2003), this relationship may vary. These variable results point to the need of further work on this subject.

\section{ACKNOWLEDGEMENTS}

To Marília de C. Brasil Sato (UFRRJ), for the identification of the mite larvae and revision of the manuscript; Mary S. Linn (The University of Oklahoma) and Joseph R. Mendelson III (The Atlanta Zoo), for the last revision of the text; Roberta R. da Silva (UFRRJ), and Renato Gomes Faria (UnB), for help in data recording; Guarino R. Colli and Mariana Zatz (UnB), for their attention during our visit to the herpetological collection of this institution (CHUNB).

\section{REFERENCES}

ARnold, E.N. 1986. Mite pockets of lizards, a possible means of reducing damage by ectoparasites. Biological Journal of Linnean Society, London, 29: 1-21.

Bauer, A.M.; A.P. Russel \& N.R. Dollahon. 1990. Skin folds in gekkonid genus Rhacodactylus: a natural test of damage limitation hypothesis of mite pocket function. Canadian Journal of Zoology, Ottawa, 68: 1196-1201.

Bauer, A.M.; A.P. Russel \& N.R. Dollahon. 1993. Function of the mite pocket of lizards: a reply to E.N. Arnold. Canadian Journal of Zoology, Ottawa, 71: 865-868.

Benton, M.J. 1987. The mite pockets of lizards. Nature, London, 325: 392

Brennan, J.M. \& J.T. Reed. 1974. The genus Eutrombicula in Venezuela (Acarina: Trombiculidae). Journal of Parasitology, Lawrence, 60 (4): 699-711.

Clopton, R.E. \& R.E. Gold. 1993. Distribution and seasonal and diurnal activity patterns of Eutrombicula alfreddugesi (Acari: Trombiculidae) in a forest edge ecosystem. Journal of Medical Entomology, Lanham, 30 (1): 47-53.

Cunha-Barros, M. \& C.F.D. RochA. 2000. Ectoparasitism by chigger mites (Eutrombicula alfreddugesi: Trombiculidade) in a restinga lizard community. Ciência e Cultura, São Paulo, 52 (2): 108-114.

Cunha-Barros, M.; M. van-Sluys; D. Vrcibradic; C.A.B. Galdino; F.H. Hatano \& C.F.D. Rocha. 2003. Patterns of infestation by chigger mites in four diurnal lizard species from a restinga habitat (Jurubatiba) of Southeastern Brazil. Brazilian Journal of Biology, São Carlos, 63 (3): 393-399.

Daniel, M. \& A.A. SteKol'Nikov. 2004. Chigger mites of the genus Eutrombicula Ewing, 1938 (Acari: Trombiculidae) from Cuba, with the description of three new species. Folia Parasitologica, Prague, 51: 359-366.

Durden, L.A.; J.H. Oliver-JR; C.W. Banks \& G.N. Vogel. 2002.
Parasitism of lizards by immature stages of the blacklegged tick, Ixodes scapularis (Acari, Ixodidae). Experimental and Applied Acarology, Amsterdam, 26: 257-266.

Faria, R.G. \& A.F.B. Araujo. 2004. Syntopy of two Tropidurus lizard species (Squamata: Tropiduridae) in a rocky Cerrado habitat in Central Brazil. Brazilian Journal of Biology, Rio de Janeiro, 64 (4): 775-786.

Frost, D.R. 1992. Phylogenetic analysis an taxonomy of the Tropidurus group of lizards (Iguania: Tropiduridae). American Museum Novitates, New York, 3033: 1-68.

Frost, D.R.; M.T. Rodrigues; T. Grant \& T.A. Titus. 2001. Phylogenetics of the lizard genus Tropidurus (Squamata: Tropiduridae: Tropidurinae): Direct optimization, descriptive efficiency, and sensitivity analysis of congruence between molecular data and morphology. Molecular Phylogenetics and Evolution, Orlando, 21 (3): 352-371.

García-de la Peña, C.; A.Contreras-Balderas; G. Castañeda \& D. LazcaNO. 2004. Infestación y distribución corporal dela nigua Eutrombicula alfreddugesi (Acari: Trombiculidae) en el lacertilio de las rocas Sceloporus couchii (Sauria: Phrynosomatidae). Acta Zoologica Mexicana (New Series), Mexico, 20 (2): 159-165.

HYLAND, K.E. JR. 1950. The copperhead snake as a host for chigger Trombicula (Eutrombicula) alfreddugesi. Journal of Parasitology, Lawrence, 36 (5): 494.

KLUKOWSKI, M. 2004. Seasonal changes in abundance of hostseeking chiggers (Acari: Trombiculidae) and infestations on fence lizards, Scel oporus undulatus. Journal of Herpetology, Athens, 38 (1): 141-144.

KREBS, C.J. 1998. Ecological Methodology. New York, Addison Wesley Longman, $2^{\text {nd }}$ ed., 581p.

McGuire, J.A. 1996. Phylogenetic systematics of Crotaphytid lizards (Reptilia: Iguania: Crotaphytidae). Bulletin of Carnegie Museum of Natural History, Pittsburgh, 32: 1143.

RodRIGUES, M.T. 1987. Sistemática, Ecologia e Zoogeografia dos Tropidurus do grupo torquatus ao Sul do Rio Amazonas (Sauria, Iguanidae). Arquivos de Zoologia, São Paulo, 31 (3): 105230.

Sorci, G.; M. Fraipont \& J. Clobert. 1997. Host density and ectoparasite avoidance in the common lizard (Lacerta vivipara). Oecologia, Berlin, 111: 183-188.

Vercammen-Grandjean, P.H. \& J.R. Audy. 1965. Revision of Eutrombicula Ewing 1938 (Acarina: Trombiculidae). Acarologia Supplements, Paris: 280-294.

Zippel, K.C.; R. Powell; J.S. Parmerlee-Jr.; S. Monks; A. Lathrop \& D.D. Smith. 1996. The distribution of Iarval Eutrombicula alfreddugesi (Acari: Trombiculidae) infesting Anolis lizards (Lacertilia: Polychrotidae) from different habitats on Hispaniola. Caribbean Journal of Science, Mayaguez, 32 (1): $43-49$.

Received in 16.II.2006; accepted in 25.IX.2006.

Revista Brasileira de Zoologia 23 (4): 1010-1015, dezembro 2006 